\title{
Study of Nickel (II) Catalysed Oxidation of Glycylglycine by Heptavalent Manganese: A Kinetic Study
}

\author{
M. Sanjana ${ }^{1 *}$, Ajay Kumar Patnaik ${ }^{2}$, Prakash Mohanty ${ }^{2}$, \\ Susanta Kumar Badamali ${ }^{3}$ \\ ${ }^{1}$ (Department of Chemistry, Christ College, Cuttack 753008, India) \\ ${ }^{2}$ (Post Graduate Department of Chemistry, Ravenshaw University, Cuttack 753001, India) \\ ${ }^{3}$ (Post Graduate Department of Chemistry, Utkal University, Bhubaneswar 751004, India)
}

\begin{abstract}
Kinetics of the $\mathrm{Ni}(\mathrm{II})$ catalysed oxidation of glycylglycine by alkaline $\mathrm{KMnO}_{4}$ has been studied spectrophotometrically over the range $2.0 \leq 10^{3}[\mathrm{Gly}-\mathrm{Gly}] \leq 6.0 \mathrm{~mol} \mathrm{dm}^{-3} ; 1.25 \leq 10^{7}[\mathrm{OH}] \leq 10.0 \mathrm{~mol} \mathrm{dm}^{-3} ; 293$ $\leq T \leq 313 \mathrm{~K}$ and $\mathrm{I}=0.5 \mathrm{~mol} \mathrm{dm}{ }^{-3}\left(\mathrm{KNO}_{3}\right)$. The reaction exhibits first order in $\left[\mathrm{MnO}_{4}^{-}\right]_{T}$ and $[\mathrm{Ni}(\mathrm{II})]_{T}$ but fractional order in both $[\mathrm{Gly}-\mathrm{Gly}]_{T}$ and $\left[\mathrm{OH}_{T}^{-}\right]_{T}$ respectively. The rate of reaction is found to increase with increase in $[\mathrm{Gly}-\mathrm{Gly}]_{T}$ and $\left[\mathrm{OH}^{-}\right]_{T}$.For uncatalysed reaction $\Delta \mathrm{H}^{\#}\left(\mathrm{kJmol}^{-1}\right)$ and $\Delta \mathrm{S}^{\#}\left(\mathrm{JK}^{-1} \mathrm{~mol}^{-1}\right)$ are found to be $44.4 \pm 1.8$ and $-182 \pm 6.0$ respectively but for $\mathrm{Ni}(\mathrm{II})$ catalysed reaction, the parameters $\Delta H^{\#}\left(\mathrm{~kJ} \mathrm{~mol}^{-1}\right)$ and $\Delta \mathrm{S}^{\#}$ $\left(\mathrm{JK}^{-1} \mathrm{~mol}^{-1}\right)$ are found to be $23.46 \pm 2.53$ and $-159.1 \pm 8.43$ respectively. The Ni(II) catalysed reaction passes through a new reaction path with less activation energy. The $\Delta H^{o}\left(\mathrm{~kJ} \mathrm{~mol}^{-1}\right)$ and $\triangle S^{o}\left(\mathrm{JK}^{-1} \mathrm{~mol}^{-1}\right)$ values for $\log K_{1}$ and $\log K_{2}$ are found to be $42.2 \&-30.6$ and280.1\&-37.9. The negative activation entropy is indicative of ordered transition state for electron transfer reaction. The product of the reaction is found to be glyoxalwhich is supported by FTIR data.
\end{abstract}

Keywords: Kinetic study, electron transfer, heptavalent manganese, glycylglycine

\section{Introduction}

Potassium permanganate is widely used as an oxidizing agent in synthetic as well as in analytical chemistry, and also as a disinfectant. The permanganate reactions are governed by the $\mathrm{pH}$ of the medium. Among the six oxidation states of manganese ( +2 to +7$)$, permanganate, $\mathrm{Mn}(\mathrm{VII})$ is the most potent oxidation state in acid as well as in alkaline medium [1-10]. The mechanism by which the multivalent oxidant oxidizes a substrate depends not only on the substrate but also on the medium [11] used for the study. In strongly alkaline medium, the stable reduction product [12-15] of the permanganate ion is manganate ion, $\mathrm{MnO}_{4}{ }^{2-}$. Few mechanistic informationare available to distinguish between a direct one-electron reduction to $\mathrm{Mn}(\mathrm{VI})$ and a mechanism, in which a hypomanganate is formed in a two-electron reduction followed by rapid oxidation of the hypomanganate ion [16-19].

Glycylglycine is the simplest of dipeptides. It is widely used as a significant biological buffer [20]because it is a non-toxic crystalline solid which is highly soluble and readily obtainable in pure form and a mild reductant. It is a normal constituent of many proteins. It is an active site residue of enzymes such as glycolate oxidase, DNPH-glyoxalatereductase which are soluble in cytoplasmic enzymes. It helps in maintaining the correct conformation of enzymes by keeping them in proper ionic state. Studies on the oxidation of the peptides may help to understand many biological processes. Thus, oxidation of these may help in understanding enzyme kinetics. The oxidation of amino acids is of interest as the products differ depending onthe oxidants [21,22].In the recent years, the use of transition metal ions as catalysts in various redox processes has attracted considerable attention [23]. Although the catalytic effects of different aqua metal ions on oxidation of several amino acids by permanganate ion and other oxidants have been reported, their effects in complex forms have not been studied. The role of $\mathrm{Ni}(\mathrm{II})$ as a catalyst has been reviewed by several workers [24]. The mechanism of catalysis depends on the nature of the substrate, oxidant and the experimental conditions. The reaction is presumed to proceed via an outer sphere electron transfer process.

\section{Materials and methods}

\section{Experimental Procedure}

All the reagents used were of A.R. grade. All solutions were prepared with doubly distilled water. Stock solution of glycylglycine (SRL) was prepared by dissolving the appropriate amount of the sample in double distilled water. The stock solution of $\mathrm{KMnO}_{4}$ (Merck) was prepared [25] and standardizedagainst oxalic acid [26].The solution of $\mathrm{Ni}$ (II) was prepared by dissolving calculated amount of $\mathrm{NiSO}_{4}$ (Merck) in double distilled water. $[\mathrm{Ni}(\mathrm{II})]$ in $\mathrm{NiSO}_{4}$ solution was determined gravimetrically as $\mathrm{Ni}(\mathrm{DMG})_{2}$. The $\mathrm{pH}$ and ionic strength of the solution was adjusted by adding $\mathrm{NaOH} / \mathrm{KNO}_{3}$ solution respectively and the $\mathrm{pH}$ measurements 
were carried out with the help of SYSTRONICS pH meterequipped with a combination of glass $\mathrm{Ag} / \mathrm{AgCl} / \mathrm{Cl}^{-}$ (3M NaCl) electrode. It was calibrated with standard buffers of $\mathrm{pH}$ 4.0, 7.0 and 9.0 (Merck). Absorbance was recorded with a CECIL CE-7200 (U. K.) UV-Visible spectrophotometer equipped with a CE-2024 thermoelectric controller. $10 \mathrm{~mm}$ quartz suprasil cuvettes were used. IR spectra were taken in Varian FTIR spectrophotometer.

\section{Kinetic procedure}

All kinetic measurements were performed under pseudo-first order conditions where [Gly-Gly] used is at least 10 fold excess over $\left[\mathrm{MnO}_{4}^{-}\right]$at a constant ionic strength of $0.5 \mathrm{~mol} \mathrm{dm}^{-3}$. The reaction was initiated by mixing previously thermostated solutions of $\mathrm{MnO}_{4}{ }^{-}$and glycylglycine which also contained required quantities of $\mathrm{NaOH}$ and $\mathrm{KNO}_{3}$ to maintain required alkalinity and ionic strength respectively. The temperature was uniformly maintained at $30 \pm 0.1^{\circ} \mathrm{C}$. The course of the reaction was followed by monitoring the decrease in absorbance of $\mathrm{MnO}_{4}^{-}$at $\lambda_{\max } 525 \mathrm{~nm}$. Earlier it was verified that there is negligible interference from other reagents at this wavelength. The pseudofirst order rate constants, $\mathrm{k}_{\mathrm{obs}}$ were evaluated fromthe relationship $\ln \left(\mathrm{A}_{\mathrm{t}}-\mathrm{A}_{\infty}\right)=\ln \left(\mathrm{A}_{0}-\mathrm{A}_{\infty}\right)-\left(\mathrm{k}_{\text {obs }}\right) \mathrm{t}$

where $A_{0}, A_{\infty}$ and $A_{t}$ denote optical density of the reaction mixture at time zero time, time ' $t$ ' and infinite time respectively. $\mathrm{A}_{\infty}$ was measured after completion of reaction. The correlation coefficients of plots used to determine $\mathrm{k}_{\mathrm{obs}}$ were found to be 0.99 in most cases.

\section{ResultsAnd Discussion}

The UV-visible time scan (Fig-1) of reaction mixture containing glycylglycine and permanganate at $\mathrm{pH}$ 7.7 shows a decrease of absorbance at 525 nmandthecolour of thesolution changed from violet to blue and then to green. The violet colour originates from the pinkcolour of permanganate and blue colourfrom hypomanganate. The change of $\mathrm{KMnO}_{4}$ solution from violet $\mathrm{Mn}$ (VII) ion to dark green $\mathrm{Mn}$ (VI) ion through the blue $\mathrm{Mn}(\mathrm{V})$ has been observed. [Mn(VII)] decreases at $525 \mathrm{~nm}$ whereas [Mn(VI)] increases at $608 \mathrm{~nm}$ during the reaction which is shown on Fig-1. The green color slowly turns into brownish due to further reduction to $\operatorname{Mn}(\mathrm{IV})$.

\section{Stoichiometry and Product analysis}

The reaction mixtures containing $\left[\mathrm{MnO}_{4}{ }^{-}\right]$ten times over [glycylglycine] at $\mathrm{pH} 7.7$ at a constant ionic strength of $0.5 \mathrm{~mol} \mathrm{dm}^{-3}$ were allowed to react for 12 hours at $30^{\circ}$ Cunder inert atmosphere. After completion of the reaction, the reaction mixture was treated with 2, 4-dinitro phenylhydrazine; a yellow solid was precipitated. The solid was separated by filtration and analyzed by FT-IR.

The results showed that two moles of $\mathrm{MnO}_{4}{ }^{-}$were consumed by one mole of Glycylglycine. The main reaction products were identified as corresponding aldehyde [27] (glyoxal) by boiling point, spot test and ammonia $[28,29]$ by Nessler's reagent and manganate by its visible spectra. $\mathrm{CO}_{2}$ was qualitatively detected by lime water test [30]. The product aldehyde was quantitatively estimated to about $78 \%$ which is evidenced by its 2,4 - DNP derivative. The nature of the aldehyde as glyoxal was confirmed by its FTIR spectrum (Fig. 2). The carbonyl stretching appeared at $1715 \mathrm{~cm}^{-1}$ and a band at $2922 \mathrm{~cm}^{-1}$ due to aldehydic $\mathrm{CO}$ and $\mathrm{CH}$ stretching respectively. The N-H stretch out of CO-NH group of glycylglycine at $1664 \mathrm{~cm}^{-1}$ is missing in the product.

\section{Effects of [Glycylglycine $]_{\mathrm{T}}$}

At a fixed $\left[\mathrm{MnO}_{4}^{-}\right]_{\mathrm{T}}=2.0 \times 10^{-4} \mathrm{~mol} \mathrm{dm}^{-3},[\mathrm{Ni}(\mathrm{II})]=2.47 \times 10^{-4} \mathrm{~mol} \mathrm{dm}^{-3}$ and ionic strength $I=0.5 \mathrm{~mol}$ $\mathrm{dm}^{-3}\left(\mathrm{KNO}_{3}\right)$, the effect of [glycylglycine] on the rate was studied in the range $2.0 \times 10^{-3}$ to $6.0 \times 10^{-3} \mathrm{~mol} \mathrm{dm}^{-3}$ at different $\mathrm{pH}$ ( 7.1 to 8.0$)$ and at different temperature ( 293 to $308 \mathrm{~K})$. The results are collected in Table 1 . The rate of reaction was found to increase with increase in [glycylglycine $]_{\mathrm{T}}$ and temperature. The plots of $\mathrm{k}_{\mathrm{obs}}$ versus $[\text { glycylglycine }]_{\mathrm{T}}$ at different $\mathrm{pH}$ are shown in Fig. 3. The rate constant increased with increase in concentration of dipeptide.

\section{Effect of $\left[\mathrm{MnO}_{4}{ }^{-}\right]_{\mathrm{T}}$ on the reaction rate}

The concentration of $\mathrm{MnO}_{4}^{-}$was varied in the range $0.5 \times 10^{-4}$ to $2.5 \times 10^{-4} \mathrm{~mol} \mathrm{dm}^{-3}$, keeping all other parameters fixed. The non-variation in the pseudo-first order rate constants at various concentrations of $\mathrm{MnO}_{4}{ }^{-}$ indicates the order in $\left[\mathrm{MnO}_{4}{ }^{-}\right]$as unity. This was also confirmed by the linearity of plots of $\log$ absorbance versus time upto $75 \%$ completion of the reaction.

\section{Effect of pH}

The effect of alkali concentration on the reaction was studied at constant ionic strength of $0.5 \mathrm{~mol} \mathrm{dm}^{-3}$ at $298 \mathrm{~K}$. The $\mathrm{pH}$ was varied from 7.1 to 8.0. The rate constant increased with increase in $\mathrm{pH}$ (Figure 4). 


\section{Effect of $\mathrm{Ni}(\mathrm{II})$}

The effect of $[\mathrm{Ni}(\mathrm{II})]_{\mathrm{T}}$ on the oxidation of glycylglycine was studied by varying the [Ni(II)] from 2.47 $\times 10^{-3}$ to $2.47 \times 10^{-5} \mathrm{~mol} \mathrm{dm}{ }^{-3}$ at $[\text { glycylglycine }]_{\mathrm{T}}=6.0 \times 10^{-3} \mathrm{~mol} \mathrm{dm}^{-3},\left[\mathrm{MnO}_{4}^{-}\right]_{\mathrm{T}}=2.0 \times 10^{-4} \mathrm{~mol} \mathrm{dm}^{-3}, \mathrm{pH}=$ 7.71 , ionic strength $I=0.5 \mathrm{~mol} \mathrm{dm}^{-3}$ at temperature $298 \mathrm{~K}$. The results are collected in Table 4 . The linearity of plots $\left(r^{2}=0.99\right)$ of $\mathrm{k}_{\mathrm{obs}}$ versus [Ni(II)] (Figure 6) shows the unit order dependence on [Ni(II)].

\section{Effect of Ionic Strength}

The effect of ionic strength was studied by varying the potassium nitrate concentration from 0.05 to 0.5 mol dm${ }^{-3}$ at constant concentration of permanganate, glycylglycine, and alkali. Increasing ionic strength had no effect on the rate of the reaction.

\section{Test for free radical}

The reaction mixture was mixed with acrylonitrile monomer and kept for $2 \mathrm{~h}$ in an inert atmosphere. On diluting with methanol, a white precipitate was formed, indicating the intervention of free radicals in the reaction. However, the blank experiment with reactants in presence of acrylonitrile did not respond to positive test for free radical formation.

\section{Effect of Temperature}

The rate of the reaction was also studied at five different temperatures with varying concentrations of glycylglycine and $\mathrm{pH}$, keeping other conditions constant. The rate constants were found to increase with the increase in temperature.

\section{Discussion}

The kinetics of oxidation of glycylglycine by alkaline $\mathrm{KMnO}_{4}$ in the presence of $\mathrm{Ni}(\mathrm{II})$ exhibitedfractional order dependence in $[\mathrm{Gly}-\mathrm{Gly}]_{\mathrm{T}}$ and $\left[\mathrm{OH}^{-}\right]_{\mathrm{T}}$. Ni(II) accelerates the rate of reaction due to reduction in activation energy. Moderate values of activation parametersfavoured the electron transfer reaction. Negative value of activation entropy indicates the ordered transition state for electron transfer reaction. The product was identified as glyoxal which was supported by FTIR spectra.

\section{Mechanism}

From the above studies, the mechanism of the reaction may be delineated as in Scheme 1.

Scheme 1<smiles></smiles><smiles>[Z6]C[R11]([O])(O)O</smiles>

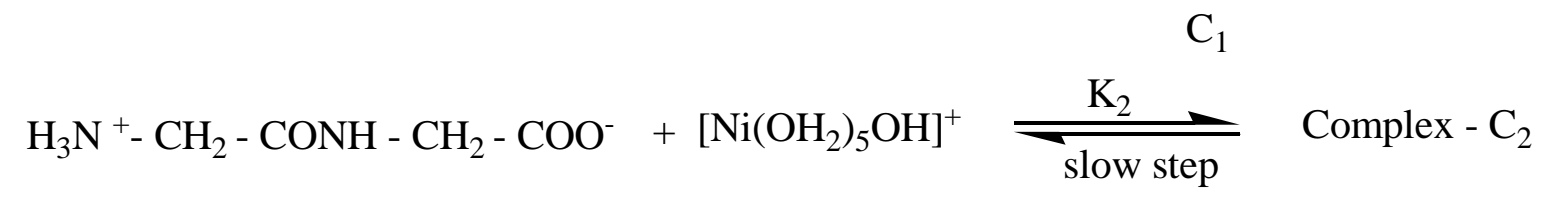

$\mathrm{k}$

$\mathrm{C}_{1}+\mathrm{C}_{2} \mathrm{P}+\left[\mathrm{Ni}\left(\mathrm{OH}_{2}\right) \mathrm{OH}^{+} \longrightarrow \mathrm{MnO}_{4}{ }^{2-}\right.$

Slow step

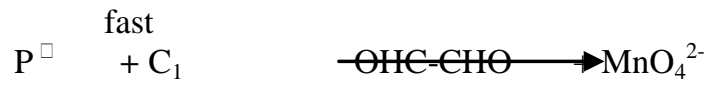

The reaction between permanganate and glycylglycine in alkaline medium has a 2:1 stoichiometry with a fractional order dependence on both the [alkali] and [Gly-Gly].

Under the conditions $\left[\mathrm{OH}^{-}\right] \gg[\mathrm{Ni}(\mathrm{II})], \mathrm{Ni}(\mathrm{II})$ is mostly presentas the hydroxylated species, $\left[\mathrm{Ni}\left(\mathrm{H}_{2} \mathrm{O}\right)_{5} \mathrm{OH}\right]^{+}$. Increase in rate with increase in $\left[\mathrm{OH}^{-}\right]$indicates the presence of the hydroxylated species of $\mathrm{Ni}(\mathrm{II})$ as a reactive species, which is shown by following equilibria in accordance with the earlier work [31]. 
$\left[\mathrm{Ni}\left(\mathrm{H}_{2} \mathrm{O}\right)_{6}\right]^{2+}+\mathrm{OH}^{-} \rightleftharpoons\left[\mathrm{Ni}\left(\mathrm{H}_{2} \mathrm{O}\right)_{5} \mathrm{OH}\right]^{+}+\mathrm{H}_{2} \mathrm{O}$

The results suggest the formation of a complex between the peptide and the hydroxylatedNi(II) species. Such complex formation between substrate and catalyst has also been observed in earlier work [32]. The formation of the complex was also proved kinetically by the intercept of the plot of [Ni (II)] / ( $\mathrm{k}_{\text {obs }}$ ) versus $1 /[$ Gly-Gly](Fig-5). Since Scheme-I is in accordance with the generally well accepted principle of noncomplementary oxidations taking place in sequence of one electron steps, the reaction between the substrate and oxidant would afford a radical intermediate. A free radical scavenging experiment revealed such a possibility. This type of radical intermediate has also been observed in earlier work on the alkaline permanganate oxidation of amino acid [33]. In agreement with the experimental results obtained, a mechanism as in Scheme-I may be envisaged.

The probable structure of the complex $\left(\mathrm{C}_{2}\right)$ is

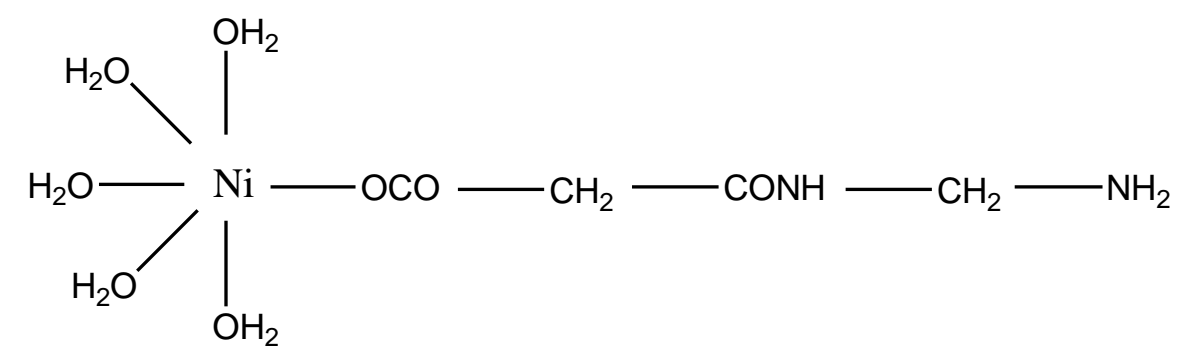

Scheme 1 leads to rate law as,

$\frac{\substack{\left.\text { Rate } \\ \mathrm{k}_{\mathrm{bus}-}^{-}\right]}}{\left[\mathrm{MnO}_{4}\right]} \quad \frac{\mathrm{kK}_{1} \mathrm{~K}_{2}[\mathrm{Gly}-\mathrm{Gly}][\mathrm{Ni}(\mathrm{II})]\left[\mathrm{OH}^{-}\right]}{1+\mathrm{K}_{1}\left[\mathrm{OH}^{-}\right]+\mathrm{K}_{2}[\mathrm{Gly}-\mathrm{Gly}]+\mathrm{K}_{1} \mathrm{~K}_{2}\left[\mathrm{OH}^{-}\right][\mathrm{Gly}-\mathrm{Gly}]}$

Equation 2 can be rearranged to equation 3 as

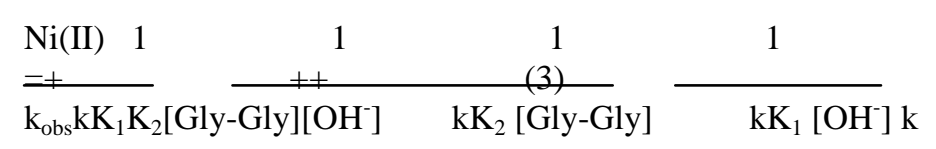

According to Eq-3 the plots of $[\mathrm{Ni}(\mathrm{II})] /\left(\mathrm{k}_{\mathrm{obs}}\right)$ versus $1 /[\mathrm{Gly}-\mathrm{Gly}]$ at constant $\left[\mathrm{OH}^{-1}\right]$ (Figure 5) and $[\mathrm{Ni}(\mathrm{II})] /\left(\mathrm{k}_{\mathrm{obs}}\right)$ versus $1 /\left[\mathrm{OH}^{-}\right]$at constant [Gly-Gly] were foundto be linear supporting the above rate law.

From $[\mathrm{Ni}(\mathrm{II})] / \mathrm{k}_{\text {obs }}$ versus $1 /\left[\mathrm{OH}^{-1}\right]$ plot at five glycylglycine concentrations produce five new slopes and five new intercepts. When these new intercepts were plotted against 1/[Gly-Gly] the second new slope will be $1 / \mathrm{kK}_{2}$ and second new intercept is $1 / \mathrm{k}$. Hence $\mathrm{k}$ and $\mathrm{K}_{2}$ were calculated. When five different new slopes were plotted against $1 /[\mathrm{Gly}-\mathrm{Gly}]_{\mathrm{T}}$, the new intercept is $1 / \mathrm{kK}_{1}$. Since $\mathrm{k}$ is known, $\mathrm{K}_{1}$ can be calculated. The electron transfer rate constants $\mathrm{k}$ and equilibrium constants $\mathrm{K}_{1}$ and $\mathrm{K}_{2}$ were calculated at five different temperatures. From the temperature variation of rate constant, activation parameters were calculated and the values are collected in Table 3 for catalyzed and uncatalysed reactions. The temperature variation of equilibrium constants and thermodynamic parameters $\Delta H^{0}$ and $\Delta S^{0}$ are collected in Table 2.

The highly negative $\Delta \mathrm{S}^{\#}$ values for both catalysed and uncatalysed reactions indicate that the reaction passes through ordered transition state.

\section{Conclusion}

The thermodynamic parameter $\mathrm{K}_{1}$ is found to increase with the increase in temperature; this indicates $\mathrm{OH}^{-}$addition is endothermic process. The other equilibrium constant $\mathrm{K}_{2}$ is found to decrease with increase in temperature. This indicates that the substitution reaction between $\left[\mathrm{Ni}_{(}\left(\mathrm{H}_{2} \mathrm{O}\right)_{5} \mathrm{OH}\right]^{+}$and glycylglycine is exothermic in nature. Negative value of activation entropy indicates ordered transition states for both catalyzed anduncatalysed reaction.

\section{Acknowledgement}

The authors are thankful to the Head of the Department of Chemistry, Christ College, Cuttack, Head of the Department of Chemistry, Utkal University, VaniViharand Head of the Department of Chemistry, Ravenshaw University, Cuttack, for providing laboratory facilities in their departments. 


\section{Reference}

[1]. P N Naik, S A ChimatadarandS T Nandibewoor, IndEngChem Res, 48(5) (2009) 2548

[2]. M Sanjana, A K Patnaik, P MohantyandS K Badamali, J of Chem, 2013 (2013) 1.

[3]. D C Bilehal, R M KulkarniandS T Nandibewoor, Canadian J of Chem, 79(12) (2001) 1926.

[4]. F Freeman, React Species Chem React, 1 (1976) 179.

[5]. R Stewart andK B Wilberg, Oxidations in Organic Chemistry Part A, Academic Press, New York, (1965) 1.

[6]. D G Lee, The Oxidations of Organic Compounds by Permanganate Ion and Hexavalent Chromium, Open Court, La Salle, (1980)

[7]. A Shaabani, F Tavasoli-Rad andD G Lee, Synthetic Communications, 35(4) (2005) 571

[8]. S Dash, S Patel andB K Mishra, Tetrahedron, 65 (2009) 707.

[9]. S M Tuwar, S T NandibewoorandJ R Raju, Trans Met Chem, 16 (1991) 335

[10]. AAleboyeh, M E OlyaandH Aleboyeh, J Hazard Mater, 162(2-3) (2009) 1530.

[11]. K A Gardner, L LKuehnertandJ M Mayer, Inorg Chem, 36 (1997) 2069.

[12]. L I Simandi, M Jaky, C R SavageandZ A Schelly, J Am ChemSoc, 107 (1985) 4220

[13]. P L Timmanagoudar, G A HiremathandS T Nandibewoor, Trans Met Chem, 22 (1997) 193.

[14]. P L Timmanagoudar, G A HiremathandS T Nandibewoor, Pol J of Chem, 70 (1996) 1459.

[15]. $\quad$ S Nadimpalli, R RallabandiandL S A Dikshitulu, Trans Met Chem, 18 (1993) 510.

[16]. A M Balado, B C GalonandF J P Marton, Ananl Quim, 88 (1992) 170.

[17]. H S Singh, R K Singh, S M SinghandA K Sisodia, J Phys Org Chem, 81 (1977) 1044.

[18]. R G Panari, A L HariharandS T Nandibewoor, J Phys Org Chem, 12 (1999) 340.

[19]. S T Nandibewoor, Hiremath andP L Timmanagoudar, Trans Met Chem, 25 (2000) 340.

[20]. M E Smith, E Smith andB Lynwood, The Biological Bulletin, 96 (3) (1949) 233

[21]. V D Chaube, S ShyleshandA P Singh, J MolCatal A, 241 (1968) 79.

[22]. W Zeng, J Li andS Quin, InorgChemCommun, 9 (2006) 10.

[23]. A G Sykes, Advances in Inorganic and Radio Chemistry, Edited by Gemeleus H \& Sharpe A G, 10 (1967) 153.

[24]. M C Kelly, G Whitaker, B White andM R Smyth, Free Rad Bio and Med, 42(11) (2007) 1680.

[25]. A Carrington andM C R Symons, J ChemSoc, 3373 (1956)

[26]. G H Jeffery, J Bassett, J Mendham andR C Denny, Vogel's Textbook of Quantitative Chemical Analysis, Fifth Ed. ELBS Longman Essen, UK, (1996) 371.

[27]. F Feigi, Spot tests in Organic Analysis, Elsevier Scientific Publishing, New York, (1975) 195.

[28]. A I Vogel, Text Book of Quantitative Chemical Analysis, $5^{\text {th }}$ Edn, ELBS, Longman Group UK, (1989) 371

[29]. A K Das and M Das, J ChemSoc Dalton Trans, 589 (1994).

[30]. S A Chimatadar, A K KiniandS T Nandibewoor, Ind J of Chem, 42(A) (2003) 1850.

[31]. P S RadhakrishnamurtyandH P Panda, Bull SocKinetInd, 2 (1980) 6.

[32]. K KSenguptaandB Basu, Ind J of Chem, 15(A) (1977) 108.

[33]. B Mohanty, J Behera, S Acharya, P Mohantyand A K Patnaik, ChemSci Trans, 2(1) (2013) 51

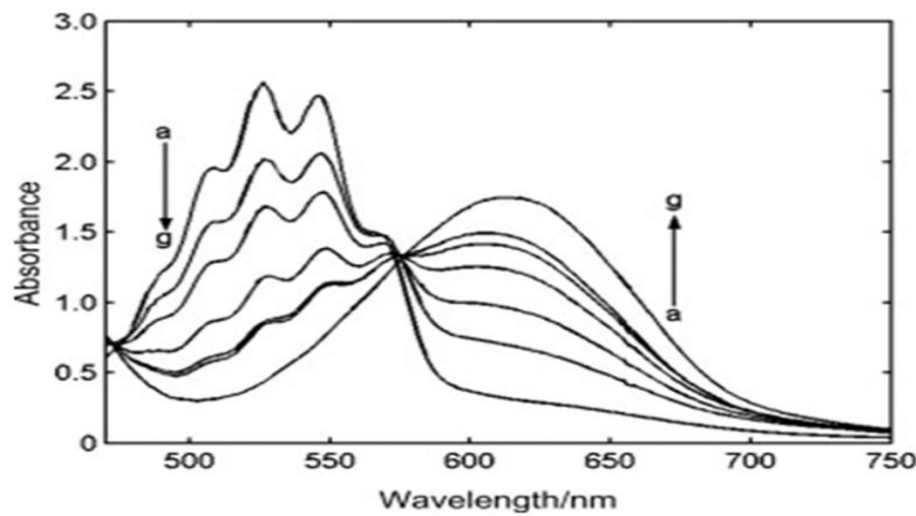

Fig.1 UV-VIS time scan of the reaction mixture of glycylglycine with $\mathrm{KMnO}_{4}$ at different time intervals; a-g each at 2 minutesinterval. [glygly] $=2 \times 10^{-3} \mathrm{~mol} \mathrm{dm}^{-3},\left[\mathrm{MnO}_{4}^{-}\right]=2 \times 10^{-4} \mathrm{~mol} \mathrm{dm}^{-3}, \mathrm{pH}=7.7, \mathrm{~T}=303 \mathrm{~K}$.

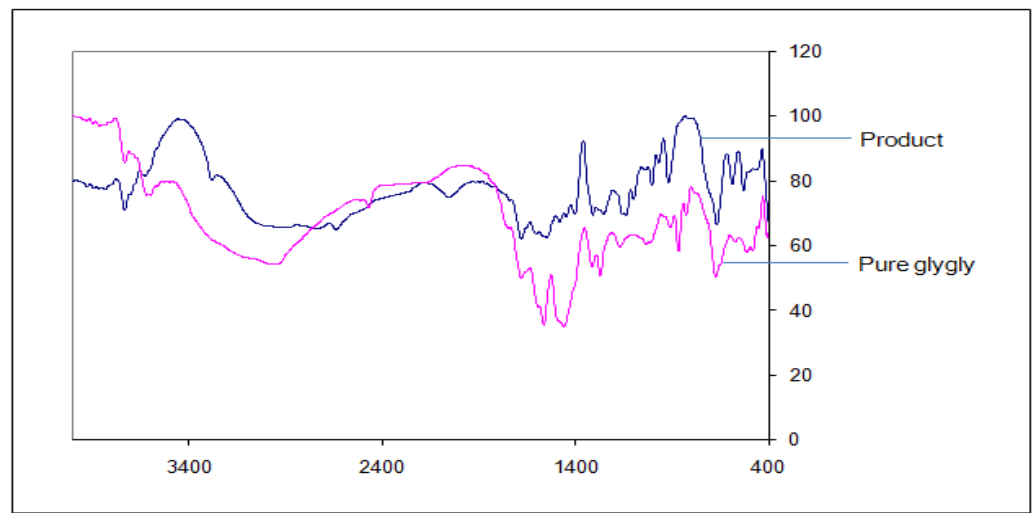

Fig.2 FTIR spectra of oxidative product of glycylglycine 


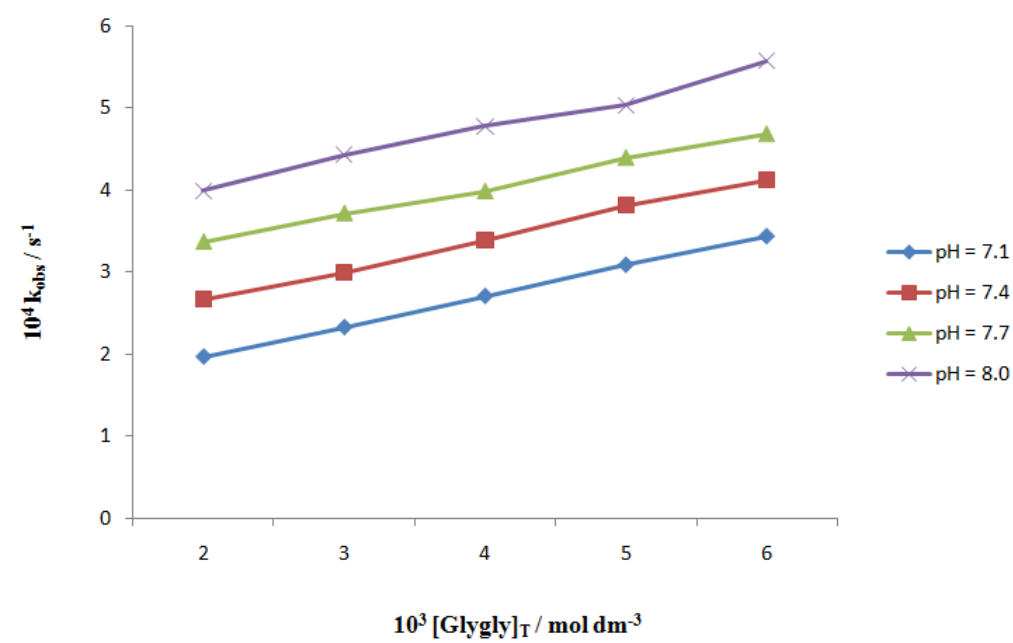

Fig. 3The Plot of $10^{4} k_{\text {obs }} / \mathrm{s}^{-1}$ versus $10^{3}[\text { Glygly }]_{\mathrm{T}} / \mathrm{mol} \mathrm{dm}^{-3}$ at different $\mathrm{pH}$. $\left[\mathrm{KMnO}_{4}\right]_{\mathrm{T}}=2.0 \times 10^{-4} \mathrm{~mol} \mathrm{dm}^{-3}$, $[\mathrm{Ni}(\mathrm{II})]_{\mathrm{T}}=2.47 \times 10^{-4} \mathrm{~mol} \mathrm{dm}^{-3} ; I=0.5 \mathrm{~mol} \mathrm{dm}^{-3}\left(\mathrm{KNO}_{3}\right) ; \mathrm{T}=298 \mathrm{~K}$. [Glygly $]_{\mathrm{T}}$ was varied from $2.0 \times 10^{-3}$ to 6.0 $\times 10^{-3} \mathrm{~mol} \mathrm{dm}^{-3}$

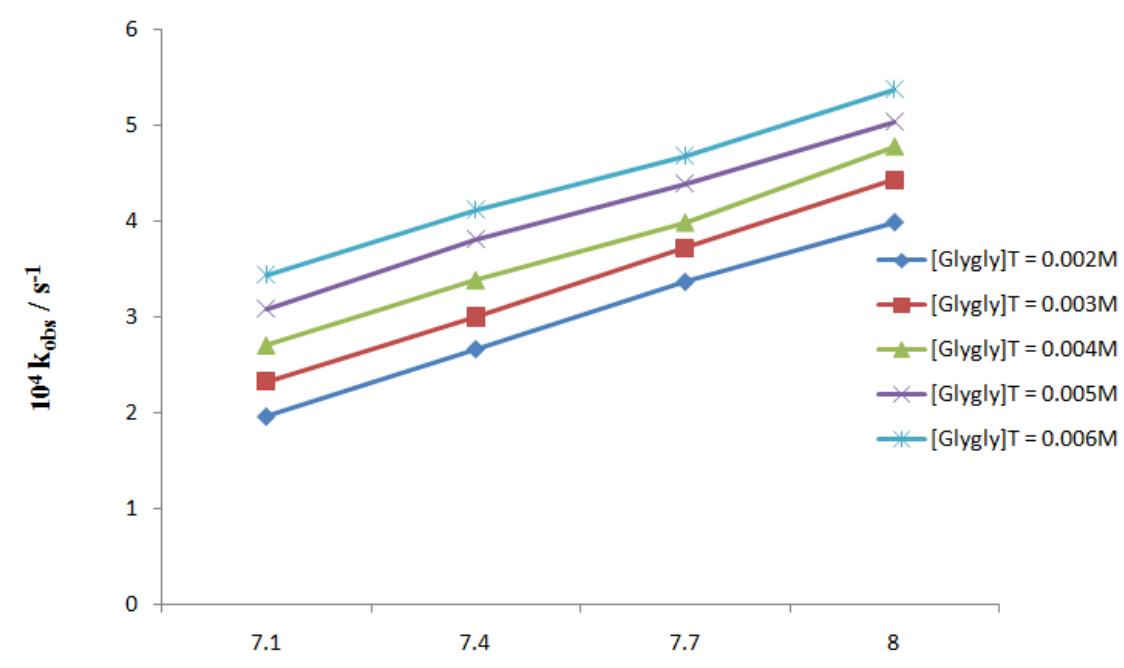

pH

Fig. 4 The Plot of $10^{4} k_{o b s} / \mathrm{s}^{-1}$ versus pH at different $[\text { Glygly }]_{\mathrm{T}} .\left[\mathrm{KMnO}_{4}\right]_{\mathrm{T}}=2.0 \times 10^{-4} \mathrm{~mol} \mathrm{dm}^{-3} ;[\mathrm{Ni}(\mathrm{II})]_{\mathrm{T}}=2.47$ $\times 10^{-4} \mathrm{~mol} \mathrm{dm}^{-3} ; I=0.5 \mathrm{~mol} \mathrm{dm}^{-3}\left(\mathrm{KNO}_{3}\right) ; \mathrm{T}=298 \mathrm{~K}$. $\mathrm{pH}$ was varied from 7.1 to 8.0

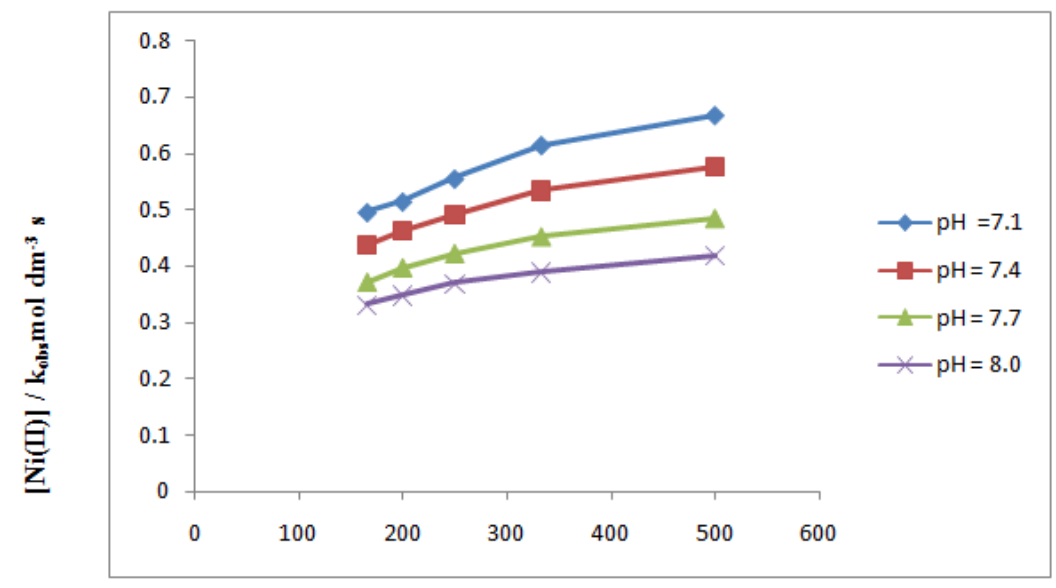

$[\text { Gly-Gly }]^{-1} / \mathbf{m o l}^{-1} \mathbf{d m}^{3}$

Fig.5[Ni(II)]/ $\mathrm{k}_{\mathrm{obs}}$ versus [glygly] ${ }^{-1}$ at different $\mathrm{pH} .\left[\mathrm{Ni}(\mathrm{II})=2.47 \times 10^{-4} \mathrm{~mol} \mathrm{dm}^{-3}, I=0.5 \mathrm{~mol} \mathrm{dm}{ }^{-3}\right.$ 


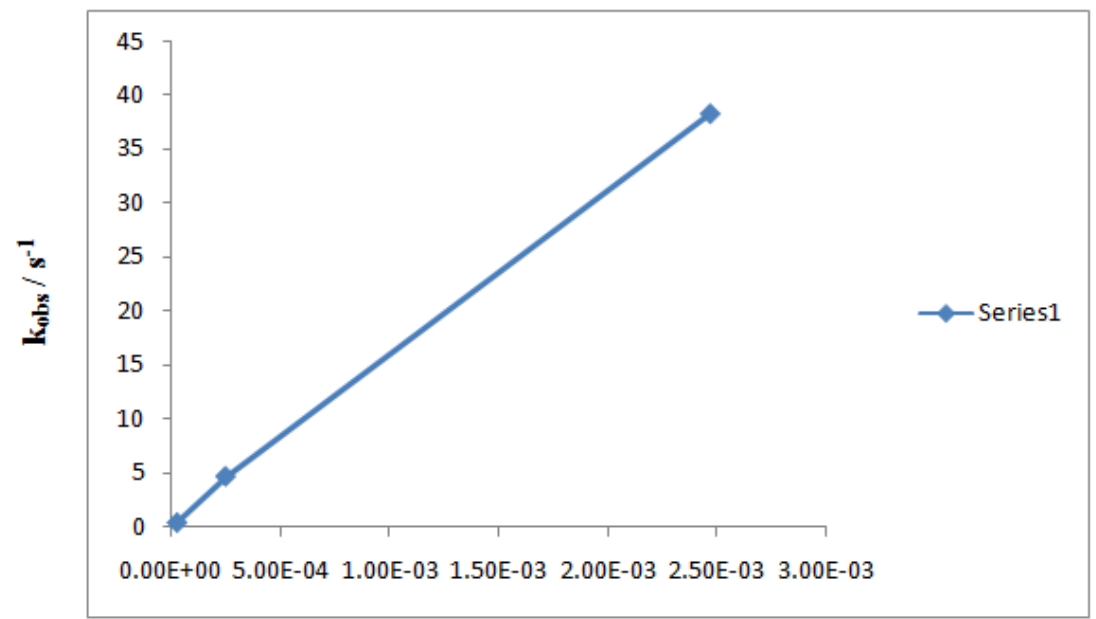

[Ni(II)] / $\mathbf{m o l ~ d m}^{-3}$

Fig.6 Effect of $[\mathrm{Ni}(\mathrm{II})]_{\mathrm{T}}$ on the oxidation of Glyglycine. $\mathrm{pH}=7.71,[\mathrm{Glygly}]_{\mathrm{T}}=6.0 \times 10^{-3} \mathrm{~mol} \mathrm{dm}^{-3},\left[\mathrm{MnO}_{4}\right]_{\mathrm{T}}$ $=2.0 \times 10^{-4} \mathrm{~mol} . \mathrm{dm}^{-3}, I=0.5 \mathrm{~mol} . \mathrm{dm}^{-3}, \mathrm{~T}=298 \mathrm{~K}$

Table 1Effect of variation of $[\text { glygly }]_{\mathrm{T}}$ and $\mathrm{pH}$ on the pseudo first order rate constant $\left(k_{\text {obs }}\right)$ at different temperatures. $\left[\mathrm{KMnO}_{4}\right]_{\mathrm{T}}=2.0 \times 10^{-4} \mathrm{~mol} \mathrm{dm}^{-3} ;[\mathrm{Ni}(\mathrm{II})]_{\mathrm{T}}=2.47 \times 10^{-4} \mathrm{~mol} \mathrm{dm}^{-3} ; I=0.5 \mathrm{~mol} \mathrm{dm}^{-3}\left(\mathrm{KNO}_{3}\right)$

\begin{tabular}{|c|c|c|c|c|c|}
\hline \multirow[t]{3}{*}{$\mathrm{T} / \mathrm{K}$} & \multirow[t]{3}{*}{$10^{3}[\text { Glygly }]_{\mathrm{T}} / \mathrm{mol} \mathrm{dm}^{-3}$} & \multicolumn{4}{|c|}{$10^{4} k_{o b s} / \mathrm{s}^{-1}$} \\
\hline & & \multicolumn{4}{|c|}{$\mathrm{pH}$} \\
\hline & & 7.1 & 7.4 & 7.7 & 8.0 \\
\hline \multirow[t]{5}{*}{293} & 2.0 & 1.17 & 1.83 & 2.50 & 3.00 \\
\hline & 3.0 & 1.52 & 2.17 & 2.85 & 3.48 \\
\hline & 4.0 & 2.00 & 2.54 & 3.17 & 3.72 \\
\hline & 5.0 & 2.66 & 3.01 & 3.43 & 4.28 \\
\hline & 6.0 & 3.02 & 3.49 & 3.83 & 4.55 \\
\hline \multirow[t]{5}{*}{298} & 2.0 & 1.97 & 2.67 & 3.37 & 3.99 \\
\hline & 3.0 & 2.33 & 3.00 & 3.72 & 4.43 \\
\hline & 4.0 & 2.71 & 3.39 & 3.99 & 4.78 \\
\hline & 5.0 & 3.09 & 3.81 & 4.40 & 5.04 \\
\hline & 6.0 & 3.44 & 4.12 & 4.69 & 5.58 \\
\hline \multirow[t]{5}{*}{303} & 2.0 & 2.80 & 3.51 & 4.22 & 4.92 \\
\hline & 3.0 & 3.19 & 3.93 & 4.63 & 5.37 \\
\hline & 4.0 & 3.52 & 4.29 & 4.99 & 5.79 \\
\hline & 5.0 & 3.93 & 4.48 & 5.41 & 6.11 \\
\hline & 6.0 & 4.34 & 5.10 & 5.80 & 6.52 \\
\hline \multirow[t]{5}{*}{308} & 2.0 & 3.70 & 4.30 & 5.09 & 5.91 \\
\hline & 3.0 & 4.02 & 4.64 & 5.46 & 6.35 \\
\hline & 4.0 & 4.45 & 5.05 & 5.85 & 6.70 \\
\hline & 5.0 & 4.80 & 5.35 & 6.23 & 7.10 \\
\hline & 6.0 & 5.22 & 5.66 & 6.67 & 7.45 \\
\hline \multirow[t]{5}{*}{313} & 2.0 & 4.58 & 5.12 & 5.80 & 6.80 \\
\hline & 3.0 & 4.95 & 5.49 & 6.30 & 7.30 \\
\hline & 4.0 & 5.31 & 5.88 & 6.74 & 7.77 \\
\hline & 5.0 & 5.68 & 6.17 & 7.05 & 8.01 \\
\hline & 6.0 & 6.11 & 6.49 & 7.44 & 8.40 \\
\hline
\end{tabular}

Table 2Equilibrium constants $\mathrm{K}_{1} \mathrm{~K}_{2}$ and thermodynamic parameters of $\mathrm{Ni}(\mathrm{II})$ catalysed oxidation of glycylglycine by alkaline permanganate

\begin{tabular}{|c|c|c|}
\hline Temp / K & $10^{-7} \mathrm{~K}_{1} / \mathrm{mol} \mathrm{dm}^{-3} \mathrm{~s}^{-1}$ & $10^{-3} \mathrm{~K}_{2} / \mathrm{mol} \mathrm{dm}^{-3} \mathrm{~s}^{-1}$ \\
\hline 293 & 1.40 & 3.02 \\
\hline 298 & 1.61 & 2.44 \\
\hline 303 & 2.03 & 2.07 \\
\hline 308 & 3.02 & 1.66 \\
\hline 313 & 4.10 & 1.34 \\
\hline & $\begin{array}{l}\left.\mathrm{mol}^{-1}\right) \\
\left.\mathrm{mol}^{-1}\right) \\
\left.\mathrm{mol}^{-1}\right) \\
\left.\mathrm{mol}^{-1}\right)\end{array}$ & $\begin{array}{l}42.2 \\
-30.6 \\
280.1 \\
-37.9\end{array}$ \\
\hline
\end{tabular}


Study of Nickel (II) catalysed oxidation of glycylglycine by heptavalent manganese: A kinetic study

Table 3 Comparison of activation parameters of Ni(II) catalysed and uncatalysed oxidation of glycylglycine by alkaline permanganate

\begin{tabular}{|l|l|l|l|}
\hline Peptide & Path & $\Delta \mathrm{H}^{\#}\left(\mathrm{KJ} \mathrm{mol}^{-1}\right)$ & $\Delta \mathrm{S}^{\#}\left(\mathrm{~J} \mathrm{~K}^{-1} \mathrm{~mol}^{-1}\right)$ \\
\hline glygly & Uncatalysed & $44.4 \pm 1.8$ & $-182.0 \pm 6.0^{33}$ \\
\hline & Catalysed / Ni(II) & $23.46 \pm 2.53$ & $-159.1 \pm 8.43$ \\
\hline
\end{tabular}

Table 4 Effect of $[\mathrm{Ni}(\mathrm{II})]_{\mathrm{T}}$ on the oxidation of Glycylglycine. $\mathrm{pH}=7.71$, $[\text { Glygly }]_{\mathrm{T}}=6.0 \times 10^{-3} \mathrm{~mol} . \mathrm{dm}^{-3}$, $\left[\mathrm{MnO}_{4}{ }^{-}\right]_{\mathrm{T}}=2.0 \times 10^{-4} \mathrm{~mol} . \mathrm{dm}^{-3}, I=0.5 \mathrm{~mol} . \mathrm{dm}^{-3}, \mathrm{~T}=298 \mathrm{~K}$

\begin{tabular}{|l|l|}
\hline$\left[\mathrm{Ni}^{2+}\right]_{\mathrm{T}} / \mathrm{mol}^{-\mathrm{dm}^{-3}}$ & $10^{4} \mathrm{k}_{\text {obs }}$ \\
\hline $2.47 \times 10^{-3}$ & 38.3 \\
\hline $2.47 \times 10^{-4}$ & 4.69 \\
\hline $2.47 \times 10^{-5}$ & 0.40 \\
\hline
\end{tabular}

